\title{
HUBUNGAN STATUS PERNIKAHAN DAN KEPEMILIKAN KONDOM DENGAN PENGGUNAAN KONDOM PADA PASANGAN TIDAK TETAP PENGGUNA NAPZA SUNTIK DI 4 KOTA DI INDONESIA
}

\author{
Sugiarto \\ Program Studi Kesehatan Masyarakat, STIKES Harapan Ibu Jambi \\ Email: mas_sugik32@yahoo.com
}

Submitted: 06-10-2017, Reviewer: 09-10-2017, Accepted: 21-08-2019

ABSTRACT

Consistency of condom use in IDU is still low. According to the STBP Report 2013, consistency of condom use in IDUs was $17 \%$ in fixed couples, $17 \%$ non-permanent couples and $16 \%$ of commercial partners. This study aims to see the determinants of condom use in IDUs in 4 cities in Indonesia. This study used STBP IDU data in 2013. The method of sampling of STBP in IDU is Respondent Driven Sampling (RDS). Data analysis is univariate, bivariate.The results showed the proportion of condom use at the time of sex with a non-permanent partner of 17\%. The result of bivariate analysis showed that there was a significant relationship between marital status $(O R=0,2$; 95\% $C I=0,1-0,6)$, condom ownership $(O R=6,6$; 95\% CI =2,4-18,2) with condom use in non-permanent partner injecting drug users in 4 cities in Indonesia.From the research results can be concluded that condom ownership is a risk factor of condom use in non-permanent partner injecting drug users. Respondents who did not have a condom had a 6.6 times higher chance of not using condoms when compared with respondents who had a condom.

Keywords: IDU, Condom Use

\begin{abstract}
ABSTRAK
Konsistensi penggunaan kondom pada Penasun masih rendah. Menurut Laporan STBP 2013, konsistensi penggunaan kondom pada Penasun sebesar 17\%pada pasangan tetap, $17 \%$ pasangan tidak tetap dan $16 \%$ pasangan komersial. Penelitian ini bertujuan untuk melihat determinan penggunaan kondom padaPenasun di 4 Kota di Indonesia. Penelitian ini menggunakan data STBP Penasuntahun 2013. Cara pengambilan sampel STBP Penasun adalah Responden DrivenSampling (RDS). Analisis data secara univariat dan bivariat.Hasil penelitian menunjukkan proporsi penggunaan kondom pada saat berhubungan seks dengan pasangan tidak tetap sebesar $17 \%$. Hasil analisis bivariat menunjukkan bahwa ada hubungan yang bermakna antara status pernikahan $(\mathrm{OR}=0,2 ; 95 \% \mathrm{CI}=0,1-0,6)$, kepemilikan kondom $(\mathrm{OR}=6,6 ; 95 \%$ $\mathrm{CI}=2,4-18,2)$ dengan penggunaan kondom pada pasangan tidak tetap pengguna napza suntik di 4 Kota di Indonesia.Dari hasil penelitian dapat disimpulkan bahwa kepemilikan kondom merupakan faktor risiko penggunaan kondom pada pasangan tidak tetap pengguna napza suntik. Responden yang tidak memiliki kondom memiliki peluang 6,6 kali lebih tinggi tidak menggunakan kondom jika dibandingkan dengan responden yang memiliki kondom.
\end{abstract}

Kata Kunci : Penasun, Penggunaan Kondom 


\section{PENDAHULUAN}

Hingga saat ini penyalahgunaan narkoba merupakan salah satupermasalahan kesehatan masyarakat di dunia. Laporan perkembangan situasinarkoba dunia tahun 2014 menunjukkan estimasi pengguna narkoba pada tahun2010 diantara 3,5-5,7\%, sedangkan pada tahun 2012 sebesar 3,5\%$7 \%$. Prevalensipenyalahgunaan narkoba di Indonesia pada tahun 2008 dilaporkan sebesar 1,99\%,tahun 2011 sebesar 2,23\%, tahun 2014 sebesar $2,18 \%$ dan pada tahun 2015, sebesar 2,20\%. Salah satu penggunaan narkoba yaitu dengan cara disuntik.Pengguna narkoba suntik pada tahun 2008 diperkirakan berjumlah 1.134.358orang, tahun 2014 sebesar 875.248 orang dan pada tahun 2015 sebesar 918.256orang (BNN, 2015).

Besarnya masalah penyalahgunaan narkoba suntik tidak hanya dari kasusnya yang meningkat, tetapi juga dampak yang ditimbulkan, mencakup fisik, psikologis dan sosial. Secara fisik penggunaan narkoba suntik berpotensi untuk tertular virus hepatitis B, C dan HIV/AIDS. Sedangkan dampak psikologis yang dirasakan oleh penasun adalah depresi, hilangnya kepercayaan diri, sulit berkonsentrasi dan sebagainya. Dampak lain yang ditimbulkan adalah dampak terhadap sosial seperti gangguan mental, anti sosial, dan dikucilkan oleh lingkungan (Martono, 2006).

HIV/AIDS telah menjadi pandemik yang mengkhawatirkan masyarakat dunia, penyakit ini juga memiliki window periode dan fase asimptomik yang relatif panjang dalam perjalanan penyakit (Depkes RI, 2007). Saat ini, HIV/AIDS menjadi permasalahan besar di Indonesia (KPAN, 2009). Epidemi HIV/AIDS yang ada di Indonesia saat ini masuk pada kategori konsentrasi dengan angka yang relatif tinggi pada kelompok kunci termasuk penasun. Penasun merupakan populasi dengan prevalensi HIV tertinggi yaitu sebesar $39,2 \%$, diikuti oleh LSL sebesar 12,8\%, Waria (7,4\%), WPSL (7\%), WPS-TL $(1,6 \%)$, WBP $(1,2 \%)$, dan Pria Resti $(0,2 \%)^{5}$ (Kemenkes, 2014).

Prevalensi HIV pada penasun di empat kota (Yogyakarta, Tangerang, Pontianak dan Makassar) mengalami kenaikan dari 27,0\% pada tahun 2009 menjadi $39,2 \%$ pada tahun 2013. Jika dibandingkan dengan tahun 2009 , prevalensi HIV tahun 2013 mengalami kenaikan di semua kota bahkan dua kali lipat tejadi di Pontianak dan Yogyakarta, kecuali Makassar yang cenderung tetap. Pontianak memiliki prevalensi HIV tertinggi dibandingkan keempat kota lainnya, yaitu sebesar 60,7\% (Kemenkes, 2014).

Kecenderungan peningkatan kasus HIV/AIDS pada kelompok kunci seperti pekerja seks dan penasun menimbulkan kekhawatiran karena berpotensi menyebar ke populasi umum. Epidemi pada pekerja seks mempunyai potensi menyebar ke populasi melalui pelangan, sedangkan epidemi pada kelompok penasun mempunyai potensi menyebar ke populasi umum melalui perilaku seksual mereka. Perwujudan potensi penularan HIV/AIDS oleh penasun ke masyarakat umum ini tergantung kepada intensitas perilaku seks mereka, siapa pasangan mereka, dan penggunaan kondom pada saat kontak seksual (KPAN, 2009).

Di Indonesia, sebagian besar program untuk mengurangi penularan HIV/AIDS dikalangan penasun hanya berfokus pada perilaku menyuntik yang tidak aman, namun ditemukan kasus bahwa penasun tidak 
hanya mempunyai pasangan tetap tetapi juga membeli seks, pasangan penasun tidak selalu penasun juga, penasun tidak selalu terbuka tentang perilaku penggunaan napza dengan pasangan seksualnya dan penasun juga menyuntik di Kota lain bersama penasun lainnya (Kemenkes, 2014). Hasil penelitian yang dilakukan oleh Felton (2003) di Rusia menunjukkan bahwa penasun yang sering berbagi jarum suntik, ternyata juga melakukan hubungan seks tidak aman dan cenderung memiliki banyak pasangan.

Penasun menggunakan atau tidak menggunakan kondom saat berhubungan seks dikarenakan beberapa alasan. Alasan menggunakan kondom paling banyak pada ketiga pasangan (pasangan tetap, tidak tetap, komersial) penasun adalah untuk mencegah HIV/IMS. Untuk pasangan tetap dan tidak tetap proporsi cukup besar menyatakan bahwa mereka menggunakan kondom untuk mencegah kehamilan. Sedangkan alasan tidak menggunakan kondom terlihat berbeda pada tiap tipe pasangan. Pada pasangan tetap, proporsi terbesar alasan tidak menggunakan kondom adalah saling mencintai dan percaya, sedangkan pada pasangan tidak tetap dan komersial, proporsi terbesarnya adalah pada alasan ketidaknyamanan menggunakan komdom. Pengenalan akan pasangan dinilai juga cukup dipertimbangkan untuk tidak menggunakan kondom (Tambunan, et al, 2010).

Berdasarkan hal tersebut, maka perlu diwaspadai bahwa penasun memiliki risiko ganda untuk menularkan HIV selain melalui alat suntik yang tidak steril tetapi juga melalui perilaku seksual yang tidak aman. Patut dijadikan bahan pertimbangan terdapat dua cara penularan HIV pada Penasun, yaitu 1) di dalam kelompoknya sendiri, yaitu melalui perilaku penyuntikan berkelompok, penggunaan alat suntik bekas dan berhubungan seks dengan sesama penasun dan 2) ke masyarakat umum, yaitu melalui hubungan seksual berisiko dengan WPS ${ }^{8}$ (Zani, 2004). Hal tersebut berpotensi pada penyebaran HIV dari Penasun kemasyarakat umum.

\section{METODOLOGI PENELITIAN}

Penelitian ini merupakan studi kuantitatif dengan menggunakan data sekunder Survei Terpadu Biologi dan Perilaku (STBP) tahun 2013, dimana survei tersebut dirancang dengan menggunakan desain studi potong lintang. Penelitian ini bertujuan untuk melihat perilaku penggunaan kondom padapengguna napza suntik di 4 Kota di Indonesia. Sumber data yang digunakan yaituSTBP tahun 2013 dengan unit analisis yaitu penasun yang berada di 4 Kota yaituYogyakarta, Tangerang, Pontianak dan Makassar.

Populasi dalam penelitian ini adalah kelompok penasun. Rancangan sampel yang digunakan pada kelompok penasun STBP 2013 adalah Responden Driven Sampling (RDS) yaitu sebuah teknik sampling secara bola salju (snowball) berdasarkan pada kuota perekrutan (yang menghindari perekrutan keseluruhan sampel dari sejumlah individu terbatas) dan intensif rangkap untuk memotivasi perekrut dan yang direkrut. RDS berawal dari sejumlah kecil peserta yang dipilih secara purposif yang biasanya disebut seed.

\section{HASIL DAN PEMBAHASAN}

\section{Analisis Univariat}

\section{a. Status Pernikahan}

Tabel 1

Distribusi Frekuensi Status Pernikahan

\begin{tabular}{lcc}
\hline Status Pernikahan & $\mathrm{n}$ & $\%$ \\
\hline Menikah & 52 & 28,3 \\
\hline
\end{tabular}




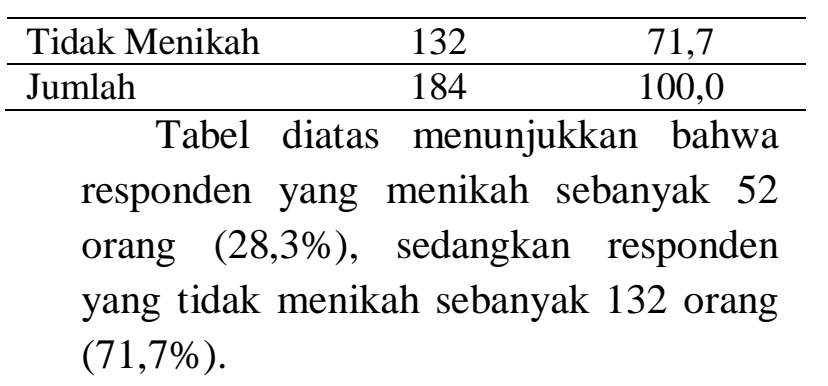

\section{b. Kepemilikan Kondom}

Tabel 2

Distribusi Frekuensi Kepemilikan Kondom Responden

\begin{tabular}{lcc}
\hline \multicolumn{1}{c}{$\begin{array}{c}\text { Kepemilikan } \\
\text { Kondom }\end{array}$} & $\mathrm{n}$ & $\%$ \\
\hline Memiliki & 70 & 38,0 \\
Tidak memiliki & 112 & 60,9 \\
Tidak menjawab & 2 & 1,1 \\
\hline Jumlah & 184 & 100,0 \\
\hline
\end{tabular}

Tabel diatas menunjukkan bahwa responden yang memiliki kondom sebanyak 70 orang $(38,0 \%)$ sedangkan yang tidak memiliki kondom sebanyak 112 orang $(60,9 \%)$

\section{c. Penggunaan Kondom}

Tabel 3

Distribusi Frekuensi Penggunaan Kondom

\begin{tabular}{lcc}
\hline \multicolumn{1}{c}{ Penggunaan } & $\mathrm{n}$ & $\%$ \\
\hline Kondom & 32 & 17,4 \\
Sering & 64 & 34,8 \\
Tidak Pernah & 88 & 47,8 \\
\hline Jumlah & 184 & 100,0 \\
\hline
\end{tabular}

Tabel diatas menunjukkan bahwa responden yang selalu menggunakan kondom saat melakukan hubungan seksual sebanyak 32 orang $(17,4 \%)$, yang sering menggunakan kondom sebanyak 64 orang $(34,8 \%)$ dan yang tidak pernah menggunakan kondom sebanyak 88 orang $(47,8 \%)$.

\section{Analisis Bivariat}

a. Hubungan Status Pernikahan dengan Penggunaan Kondom Pada Pengguna

\section{Napza Suntik saat Melakukan Hubungan Seksual}

Tabel 4

Hubungan Status Pernikahan dengan Penggunaan Kondom Pada Pengguna Napza Suntik saat Melakukan Hubungan Seksual

\begin{tabular}{lccccc}
\hline \multirow{3}{*}{$\begin{array}{c}\text { Status } \\
\text { Pernikahan }\end{array}$} & \multicolumn{5}{c}{ Penggunaan Kondom } \\
\cline { 2 - 6 } & $\begin{array}{c}\text { Selalu } \\
(\%)\end{array}$ & $\begin{array}{c}\text { Sering } \\
(\%)\end{array}$ & $\begin{array}{c}\text { Tidak } \\
\text { Pernah } \\
(\%)\end{array}$ & n & OR \\
\hline Menikah & 9,6 & 32,7 & 57,7 & 52 & 0,5 \\
Tidak & 20,5 & 35,6 & 43,9 & 13 & \\
Menikah & & & & 2 & \\
\hline
\end{tabular}

Tabel diatas menunjukkan bahwa responden yang menikah dan melakukan hubungan seks dengan pasangan tidak tetap serta selalu menggunakan kondom sebesar 9,6\%, sering menggunakan kondon sebesar 32,7\% dan tidak pernah menggunakan kondom sebesar 57,7\%. Sedangkan responden yanag tidak menikah dan melakukan hubungan seks dengan pasangan tidak tetap serta selalu menggunakan kondom sebesar 20,5\%, sering menggunakan kondom 35,6\% dan tidak pernah menggunakan kondom sebesar $43,9 \%$.

Hasil penelitian menunjukkan bahwa ada asosiasi antara status pernikahan dengan penggunaan kondom pada pasangan tidak tetap penasun. penasun yang tidak menikah memiliki kecenderungan 0,5 kali lebih rendah tidak menggunakan kondom pada hubungan seksual dengan pasangan tidak tetap sebulan terakhir jika dibandingkan dengan penasun yang sudah menikah. Hasil penelitian Silawati (2010), menunjukkan bahwa responden yang belum menikah memiliki kecenderungan 0,7 kali lebih rendah tidak menggunakan 
kondom jika dibandingkan dengan responden yang sudah menikah.

Status perkawinan diduga memiliki peranan seksual seseorang. Laki-laki yang sudah menikah diperkirakan memiliki kegiatan seksual berbeda dengan lakilaki yang belum menikah. Logikanya laki-laki yang sudah menikah akan berperilaku sehat dan bertanggungjawab dalam melakukan hubungan seksual dengan pasangannya karena tidak menginginkan dampak negatif dari hubungan seks tersebut. Secara teoritis seseorang yang berstatus belum/tidak menikah mempunyai tingkat perilaku seks yang lebih berisiko, karena untuk melampiaskan hasrat seksualnya mereka cenderung untuk mengakses pekerja seks komersial.

b. Hubungan Kepemilikan Kondom dengan Penggunaan Kondom Pada Pengguna Napza Suntik saat Melakukan Hubungan Seksual

Tabel 5

Hubungan Kepemilikan Kondom dengan

Penggunaan Kondom Pada Pengguna Napza

Suntik saat Melakukan Hubungan Seksual

\begin{tabular}{lccccc}
\hline & \multicolumn{5}{c}{ Penggunaan Kondom } \\
\cline { 2 - 6 } $\begin{array}{c}\text { Kepemilikan } \\
\text { Kondom }\end{array}$ & $\begin{array}{c}\text { Selalu } \\
(\%)\end{array}$ & $\begin{array}{c}\text { Sering } \\
(\%)\end{array}$ & $\begin{array}{c}\text { Tidak } \\
\text { Pernah } \\
(\%)\end{array}$ & n & OR \\
\hline Memiliki & 27,1 & 47,1 & 25,7 & 70 & 1,3 \\
Tidak & 11,6 & 26,6 & 61,6 & 112 & \\
Memiliki & & & & & \\
\hline
\end{tabular}

Tabel diatas menunjukkan bahwa responden yang memiliki kondom dan melakukan hubungan seks dengan pasangan tidak tetap serta selalu menggunakan kondom sebesar 27,1\%, sering menggunakan kondon sebesar $47,1 \%$ dan tidak pernah menggunakan kondom sebesar 25,7\%. Sedangkan responden yanag tidak memiliki kondom dan melakukan hubungan seks dengan pasangan tidak tetap serta selalu menggunakan kondom sebesar $11,6 \%$, sering menggunakan kondom $26,6 \%$ dan tidak pernah menggunakan kondom sebesar $61,6 \%$.

Kecenderungan seseorang untuk menggunakan seseuatu akan didorong oleh ketersediaan sarana prasana. Dalam konteks pencegahan HIV pada penasun, ketersediaan kondom sangat penting. Penasun yang tidak memiliki kondom mempunyai peluang lebih tinggi tidak menggunakan kondom saat melakukan hubungan seks sebulan terakhir jika dibandingkan dengan penasun yang memiliki kondom.

Berbagai alasan yang muncul untuk tidak memiliki kondom atau menggunkan kondom yaitu merasa tidak nikmat untuk melakukan hubungan seks dengan, pasangan tidak tetap karena kondom licin dan dingin. Selain itu, mereka tidak perlu menggunakan kondomsebagai pelindung karena mereka sudah kenal dengan pasangan seksnya. Hasilpenelitian Basuki, et al (2002), pelanggan tidak menggunakan kondom karenamereka sudah kenal dengan wanita pekerja seks yang menjadi langanannya.Pelanggan menganggap bahwa berhubungan seks dengan wanita pekerja seksseperti mereka saat berhubungan seks dengan istrinya, sehingga tidakmembutuhkan Kondom.

\section{SIMPULAN}

Status pernikahan dan kepemilikan kondom berhubungan dengan penggunaan kondom saat melakukan hubungan seksual pada pasangan tidak tetap penasun.

\section{DAFTAR PUSTAKA}


Badan Narkotika Nasional, (2015). Profil Laporan Badan Narkotika Nasional Tahun 2015. Jakarta

Depkes, RI, (2007). Survei Terpadu Biologis Perilaku Pada Kelompok Berisiko Tinggi, 2007 (STBP). Jakarta

Kemenkes. RI, (2014). Laporan Hasil Survei Terpadu Biologis dan Perilaku tahun 2013. Jakarta: Dirjen P2PL

KPAN, (2009). AnalisisSituasi HIV\&AIDS di Indonesia. Outline KPA onICAAP9. Jakarta

Martono, L Harlina, Satya Joewana, (2006). Modul Latihan Pemulihan Pecandu Narkoba Berbasis Masyarakat. Jakarta: BalaiPustaka.
Silawati, Vivi, (2010). Faktor-Faktor yang Berhubungan dengan Penggunaan Komdom Pada Gay Di Jakarta Tahun 2010. Thesis. FKM UI. Depok

Tambunan, Kamil, Prapthoraharjo, Erlan, \&Irwanto, (2010). JaringanSeksualdanPenggunaanNapza padaPenggunaNapzaSuntik di 6 Propinsi. UnikaAtma Jaya: Lembaga Penelitian dan Pengabdian kepada Masyarakat.

Zani, Andri Y, Prima, (2004). Potensi Penyebaran HIV dari Pengguna Napza Suntik ke Masyarakat Umum di Jakarta. Thesis. Depok: FKM UI. 